\title{
Reaction of Candida albicans cells of different morphology index with monoclonal antibodies specific for the hyphal form
}

\author{
L. A. MERSON-DAVIES, V. HOPWOOD*, R. ROBERTt, A. MAROT-LEBLONDt, J.-M. SENET† \\ and F. C. ODDS $\ddagger$
}

Department of Microbiology, University of Leicester, * Department of Microbiology, University of Leeds, + Laboratoire d'Immunologie, Université D'Angers, France, and $\ddagger$ Department of Bacteriology and Mycology, Janssen Research Foundation, B-2340 Beerse, Belgium

\begin{abstract}
Summary. Two monoclonal antibodies (MAbs), 3D9 with reported specificity for Candida albicans hyphae, and 3B7 with reported specificity for morphological forms of $C$. albicans found in vivo, were tested by indirect immunofluorescence with $C$. albicans cells that were grown in 12 different environments (four different culture media incubated at various temperatures) and whose cellular morphology was estimated in terms of morphology index (Mi). Both MAbs reacted strongly with cells with $\mathrm{Mi}>3 \cdot 0$, i.e., with pseudohyphal and hyphal forms, but in Eagle's medium at $26^{\circ} \mathrm{C}$ and in a modified Sabouraud's broth medium at $30^{\circ} \mathrm{C}$, some reactivity was also found with cells of lower $\mathrm{Mi}$ (i.e., yeast forms). Therefore, it was concluded that the hyphal phenotype and the epitopes reactive with the MAbs were co-expressed but that the epitopes could also be expressed independently of the hyphal phenotype. The results confirm the propensity of $C$. albicans for variation of its surface antigenic composition.
\end{abstract}

\section{Introduction}

The existence of antigenic differences between the yeast and hyphal forms of Candida albicans has been known for many years. ${ }^{1,2}$ Several investigators have now prepared polyclonal antibodies ${ }^{3-8}$ and monoclonal antibodies (MAbs) ${ }^{9,10}$ that react specifically or predominantly with $C$. albicans hyphae in indirect immunofluorescence tests. Such antibodies usually show no reaction with $C$. albicans yeast cells grown in vitro, but reactions with yeast cells in tissues of experimentally infected animals have sometimes been described. ${ }^{10}$

Brawner et al. ${ }^{11}$ have shown that expression of surface antigens by $C$. albicans in immunofluorescence tests can vary temporally and with the strain of candida used, and they recommended that experiments with apparent morphology-specific surface epitopes should ideally involve more than one $C$. albicans strain and several different growth media. The advent of an objective, quantitative method for measurement of morphological form in C. albicans (morphology index, $\mathrm{Mi}^{12}$ ) provides a better situation than before for assessment of surface antigen expression, since reactions in immunofluorescence tests can be related to morphology on a cell by cell basis: each

Received 22 Nov. 1990 ; revised version accepted 9 Jan. 1991. $\ddagger$ Correspondence should be sent to Dr F. C. Odds. cell can be individually measured to determine its $\mathrm{Mi}$ and that individual cell's fluorescence can be scored. The present investigation was undertaken to study the morphological specificity of two MAbs that appear to react predominantly with hyphal forms of $C$. albicans. Mi was used as the basis for morphology determination and the yeast was grown in various different growth environments selected to provide a wide range of cell morphologies.

\section{Materials and methods}

\section{Fungus}

C. albicans strain 73/055 was used in all experiments. It was maintained by subculture on Sabouraud's glucose agar and inocula were prepared by suspension of overnight growth of yeasts on this medium in water. Cell concentrations were estimated by haemocytometer counting and the volume of cell suspension used to inoculate broth media was calculated to give an initial yeast concentration of $10^{6} / \mathrm{ml}$.

To generate cultures with various $C$. albicans morphologies, 13 different growth environments were used, and the cultures were incubated for $3 \mathrm{~h}$. The growth conditions used were: Eagle's Minimal Essential Medium (EMEM; Gibco) without L-glutamine and buffered to $\mathrm{pH} 7 \cdot 2$ with $0.02 \mathrm{M}$ HEPES, incubated 
at $26^{\circ} \mathrm{C}, 30^{\circ} \mathrm{C}, 37^{\circ} \mathrm{C}$ and $40^{\circ} \mathrm{C}$; Yeast Nitrogen Base (Difco) with glucose $10 \mathrm{~g} / \mathrm{L}$ (YNBG), incubated at $26^{\circ} \mathrm{C}, 30^{\circ} \mathrm{C}, 37^{\circ} \mathrm{C}$ and $40^{\circ} \mathrm{C}$; modified Sabouraud's broth $\left(\mathrm{MSAB}^{13}\right)$ incubated at $30^{\circ} \mathrm{C}, 35^{\circ} \mathrm{C}$ and $40^{\circ} \mathrm{C}$; Sabouraud's glucose broth (SGB; Oxoid) incubated at $30^{\circ} \mathrm{C}$; and horse serum (Difco) incubated at $37^{\circ} \mathrm{C}$.

Cells were harvested by centrifugation at $3000 \mathrm{~g}$ for $10 \mathrm{~min}$, washed twice with water and resuspended in water. The concentration of cells was adjusted to $10^{7} / \mathrm{ml}$ and $20-\mu$ l samples were placed as spots on glass microscope slides, dried in air and heat-fixed. Fixed slides were individually wrapped and stored at $-20^{\circ} \mathrm{C}$ until used. ${ }^{14}$

\section{Indirect immunofluorescence assay (IFA)}

Two murine MAbs, both of which originated in France, were used in the experiments. MAb 3D9 was prepared in Angers and MAb 3B7 was prepared in Lille. The preparations of both MAbs used in these experiments were from murine ascitic fluid. Preliminary experiments to determine optimal reactivity in the IFA test led to routine use of MAb 3D9 undiluted and MAb 3B7 diluted 20-fold in phosphate-buffered saline (PBS). To test reactivity of the MAbs against C. albicans cells, an IFA procedure based on the one described by Page and Odds ${ }^{15}$ was used. To each heatfixed specimen of cells was added $20 \mu \mathrm{l}$ of MAb and the slides were incubated in a moist chamber at $37^{\circ} \mathrm{C}$ for $30 \mathrm{~min}$. The slides were washed three times with fresh lots of PBS for periods of 3,5 and $7 \mathrm{~min}$ then $20 \mu \mathrm{l}$ of fluorescein-conjugated goat anti-mouse immunoglobulin (Sera-Lab), diluted 20-fold in PBS, was added. The slides were re-incubated at $37^{\circ} \mathrm{C}$ for $30 \mathrm{~min}$ and washed twice in PBS (30 min for each wash). The slides were dried in air and viewed on the same day whenever this was possible. Non-specific reactivity was assessed by means of control slides without cells, without the MAb addition and without addition of the fluorescent conjugate. Slides were viewed by a single operator, blinded to the source of the slides, with a Leitz ultraviolet microscope and a $\times 50$ waterimmersion objective. Fluoresence intensity was scored subjectively on a scale of 0 to $3+$. Individual cells or cell units within hyphae almost always gave a uniform fluorescence so that no attempt was made to assess variations in fluorescence between different parts of a cell or hyphal unit.

\section{Morphology index (Mi)}

The morphology of $C$. albicans cells as viewed microscopically was expressed in terms of the $\mathrm{Mi}$, a dimensionless ratio which was calculated from measurements obtained with the aid of a computerised image analysis system (Imagan; Kompira, Strathclyde). The length, maximum diameter and septal diameter of each separate cell or cell unit within conjoined cells was determined and used for calculation of Mi as described by Merson-Davies and Odds. ${ }^{12}$
Mi up to 1.5 usually indicates a spherical or spheroidal cell; $\mathrm{Mi}$ of $\geqslant 3.4$ usually indicates a parallel-sided cylindrical cell, i.e., a true hyphal unit.

\section{Analysis of results}

For each sample, the fluorescence intensity and $\mathrm{Mi}$ of 100 cells or cell units was determined. Cells scored as 0 or $1+$ by IFA were counted as "negative" by IFA; cells scored as $2+$ or $3+$ were counted as "positive". Cells in each sample were grouped according to their $\mathrm{Mi}$ in intervals of 0.5 , and the percentage of IFA-positive cells in each interval was determined. For each set of growth conditions, two or three separate samples were prepared.

\section{Results}

For each of the samples it was apparent that MAbs 3D9 and 3B7 often gave stronger fluorescence reactions with cells that fell into the higher Mi groups, indicating a preferential expression of the 3D9 and 3B7 epitopes by hyphal cells. However, there was considerable variation in patterns of reactivity, which appeared to be related to both the composition of the medium and the temperature of incubation. The results were very similar with both MAbs.

Cells grown in serum (mean Mi 3.5) showed no reactivity in the IFA tests. This was considered to be the result of blocking of reactive sites by serum proteins, many of which bind avidly to the surface of C. albicans hyphae ${ }^{15,16}$ results with cells grown in serum were, therefore, ignored. For cells grown in YNBG, the overall level of IFA reactivity with the MAbs was quite low; at $\mathrm{MI}<3 \cdot 5$, fewer than half of the cells were scored as positive by IFA. By contrast, in EMEM, most cells fluoresced strongly at temperatures higher than $26^{\circ} \mathrm{C}$. Fig. 1 illustrates the distributions of IFA positivity with 3D9 among cells grown at three different temperatures in these two media.

Fewer than $25 \%$ of all the cells grown in MSAB at $30^{\circ} \mathrm{C}$ (mean $\mathrm{Mi} 2$ ) were IFA-positive, and none of the cells grown in $\mathrm{SGB}$ at $30^{\circ} \mathrm{C}$ (mean Mi 1.75) was IFApositive. At higher temperatures in MSAB, IFAreactivity was confined almost entirely to the cells with $\mathrm{Mi}>2 \cdot 5$, i.e., the pattern with MSAB resembled those for YNBG in fig. 1 .

To gain an impression of the overall relation between Mi and expression of the two MAb epitopes, data from all the experiments were pooled to allow determination of IFA positivity for each increment of $\mathrm{Mi}$ independent of growth conditions. The result (fig. 2) indicates the distribution of 3D9 and 3B7 expression as a function of $\mathrm{Mi}$ calculated from measurement of more than 3000 cells grown in 12 different environments for each MAb. It is evident from fig. 2 that, for both MAbs, the epitope was expressed predominantly by cells with $\mathrm{Mi}>3 \cdot 0$, and that fewer than $20 \%$ of cells with $\mathrm{Mi}<2.5$ expressed either epitope. The IFA 

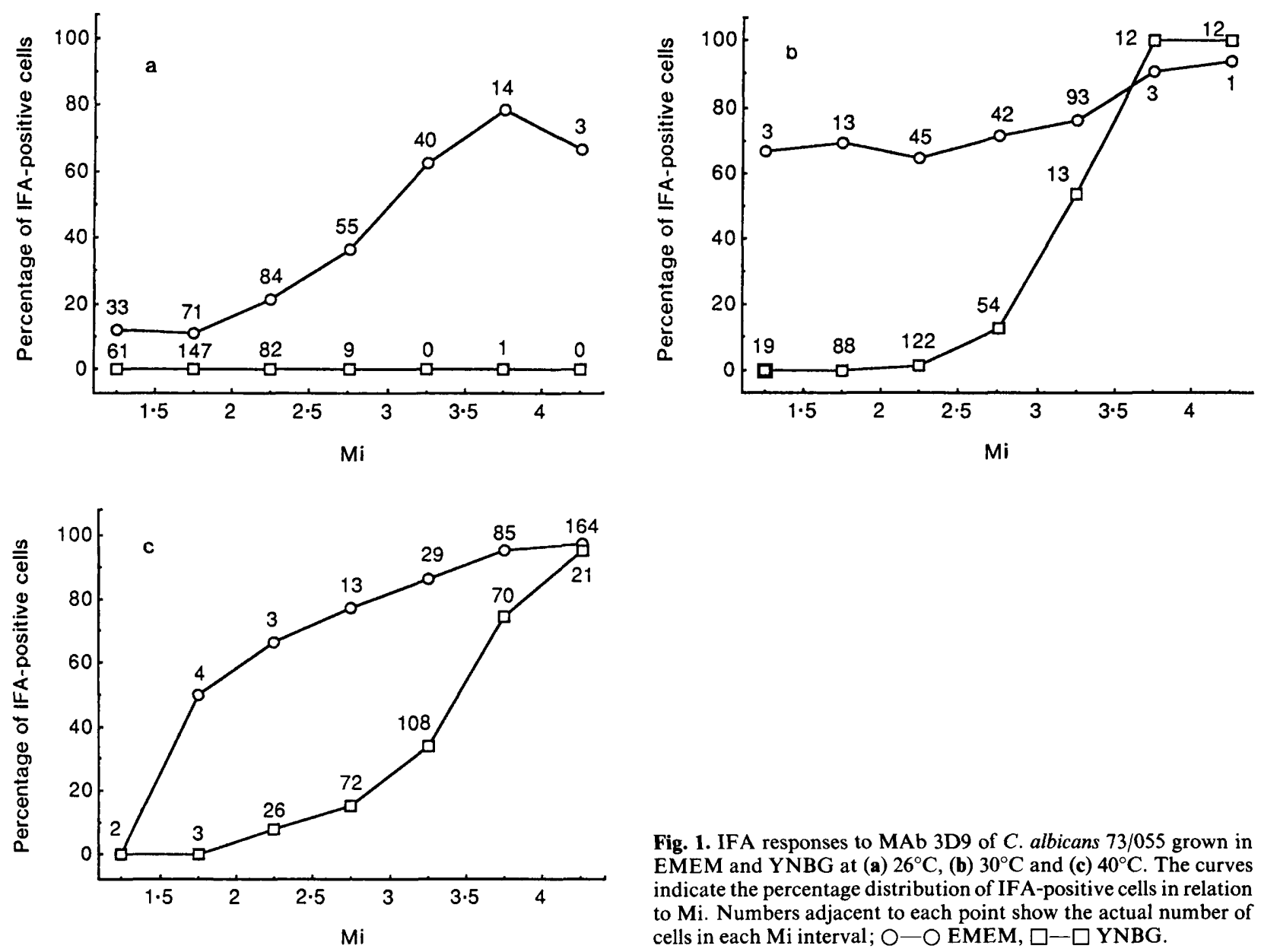

Fig. 1. IFA responses to MAb 3D9 of C. albicans 73/055 grown in EMEM and YNBG at (a) $26^{\circ} \mathrm{C}$, (b) $30^{\circ} \mathrm{C}$ and (c) $40^{\circ} \mathrm{C}$. The curves indicate the percentage distribution of IFA-positive cells in relation to Mi. Numbers adjacent to each point show the actual number of cells in each Mi interval; O-O EMEM, $\square-\square$ YNBG.

reactivity of MAb 3B7 was slightly higher than that of MAb 3D9 for cells with $\mathrm{Mi}<2 \cdot 5$. Expression of the epitopes by more than $90 \%$ of the cells was found only for cells with $\mathrm{Mi}>4 \cdot 0$.

\section{Discussion}

Brawner et al. ${ }^{11}$ mentioned three aspects of experimentation on surface antigen expression, detected in C. albicans by IFA, in which failure to take account of possible variables might lead to invalid interpretation of findings in relation to cell morphology. They considered that all such experiments should take account of possible strain variations, temporal variations and variations due to growth environment. In the present study, constraints of resources restricted our work to a single strain of $C$. albicans grown for a single time period; however, the use of a wide variety of growth conditions for the candida confirmed that expression of the 3D9 and 3B7 epitopes was influenced by the choice of growth conditions. We believe our inability to explore strain and temporal variations was partly offset by our use of $\mathrm{Mi}$ as an objective marker of cell morphology that facilitated the interpretation of morphological observations made with cells from different environments.

For the C. albicans strain studied, and for cells

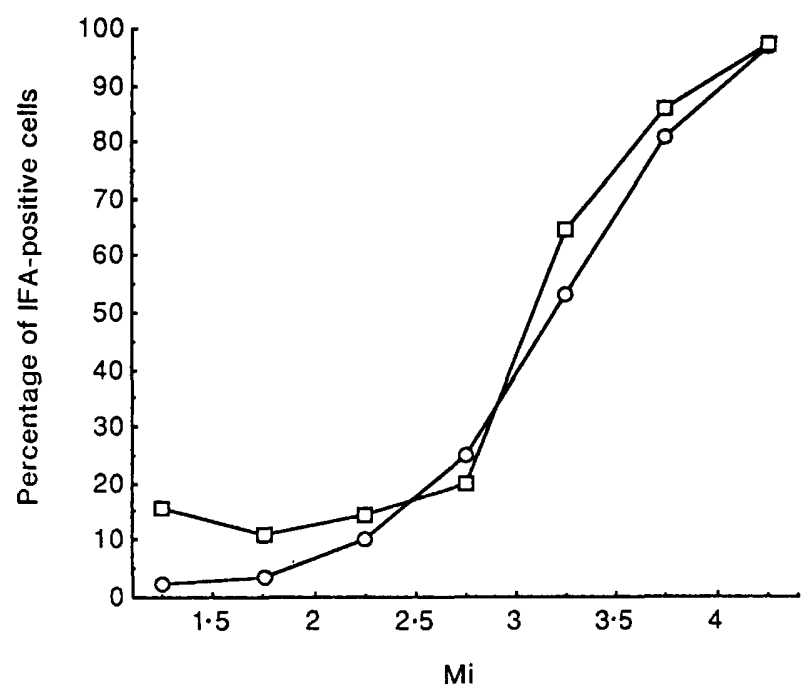

Fig. 2. IFA responses to MAbs 3D9 and 3B7 as a function of Mi. The percentage of IFA-positive cells in each Mi interval was determined from data for 12 different growth environments. The curves were, therefore, derived from measurements involving more than 3000 individual $C$. albicans cells; $\mathrm{O}-\mathrm{O}$ MAb 3D9, $\square-\square$ MAb 3B7.

grown for $3 \mathrm{~h}$, it was clear that the overall reaction of MAbs 3D9 and 3B7 was primarily with cells that had an $\mathrm{Mi}>3.0$ (fig. 2). This means the epitopes were expressed mainly by long pseudohyphal cell units and by true hyphal cell units, as was claimed by their 
originators $^{10}$ (A. Marot-Leblond, unpublished). However, in some growth environments, particularly EMEM (fig. 1), some $C$. albicans blastospores also expressed the epitope; a finding that confirms previous accounts of the extreme variability of expression of surface antigens by $C$. albicans. ${ }^{3,9,11,17-20}$ There are evidently particular growth environments that favour both the hyphal phenotype and the expression of the 3D9 and 3B7 epitopes, but the latter can also be expressed independently of hypha formation. The significance of expression of these epitopes to the pathogenesis of candida infections remains a matter of conjecture, but it is notable that Fortier et al. ${ }^{10}$ found strong reactions between MAb 3B7 and nearly

\section{References}

1. Evans EGV, Richardson MD, Odds FC, Holland KT Relevance of antigenicity of Candida albicans growth phases to diagnosis of systemic candidiasis. Br Med J 1973; 4: 86-87.

2. Syverson RE, Buckley HR, Campbell CC. Cytoplasmic antigens unique to the mycelial or yeast phase of Candida albicans Infect Immun 1975; 12 : 1184-1188.

3. Poulain D, Tronchin G, Vernes A, Popeye R, Biguet $J$. Antigenic variations of Candida albicans in vivo and in vitro-relationships between $\mathrm{P}$ antigens and serotypes. Sabouraudia 1983; 21 : 99-112.

4. Smail EH, Jones JM. Demonstration and solubilization of antigens expressed primarily on the surfaces of Candida albicans germ tubes. Infect Immun 1984; 45: 74-81.

5. Sundstrom PM, Kenny GE. Characterization of antigens specific to the surface of germ tubes of Candida albicans by immunofluorescence. Infect Immun 1984; 43: 850-855.

6. Anderson JM, Soll DR. Unique phenotype of opaque cells in the white-opaque transition of Candida albicans. $J$ Bacterio $1987 ; 169$ : $5579-5588$.

7. Quindós G, Pontón J, Cisterna R. Detection of antibodies to Candida albicans germ tube in the diagnosis of systemic candidiasis. Eur J Clin Microbiol 1987; 6: 142-146.

8. Sundstrom PM, Nichols EJ, Kenny GE. Antigenic differences between mannoproteins of germ tubes and blastospores of Candida albicans. Infect Immun 1987; 55: 616-620.

9. Brawner DL, Cutler JE. Variability in expression of cell surface antigens of Candida albicans during morphogenesis. Infect Immun 1986; 51 : 337-343.

10. Fortier B, Hopwood V, Poulain D. Electric and chemical fusions for the production of monoclonal antibodies reacting with the in-vivo growth phase of Candida albicans. J Med Microbiol 1988; 27: 239-245. all the $C$. albicans cells found in infected tissues in vivo, regardless of their morphology.

Fruit et $a .^{21}$ demonstrated clonal variation in expression of a C. albicans surface epitope named 5B2. Therefore, it is possible that clonal selection pressures within tissues may determine the pathological outcome of encounters between $C$. albicans and mammalian hosts; alternatively, the micro-environment within host tissues may favour expression of certain surface epitopes and these epitopes may be associated with virulence. Elucidation of these pathogenic processes at the molecular level and their relation to morphological phenotype in C. albicans will be the subject of future research.

11. Brawner DL, Cutler JE, Beatty WL. Caveats in the investigation of form-specific molecules of Candida albicans. Infect Immun 1990; 58: 378-383.

12. Merson-Davies LA, Odds FC. A morphology index for characterization of cell shape in Candida albicans. $J$ Gen Microbiol 1989; 135: 3143-3152.

13. Evans EGV, Odds FC, Richardson MD, Holland KT. Optimum conditions for initiation of filamentation in Candida albicans. Can J Microbiol 1975; 21 : 338-342.

14. Hopwood V, Poulain D, Fortier B, Evans G, Vernes A. A monoclonal antibody to a cell wall component of Candida albicans. Infect Immun 1986; 54 : 222-227.

15. Page S, Odds FC. Binding of plasma proteins to Candida species in vitro. J Gen Microbiol 1988; 134: 2693-2702.

16. Annaix V, Aubry J. Robert R, Bouali A, Tronchin G, Senet J-M Fibrinogen binding of Candida albicans germ tubes and mycelium. Protides Biol Fluids $1987 ; 35$ : 399-402.

17. Brawner DL, Cutler JE. Cell surface and intracellular expression of two Candida albicans antigens during in vitro and in vivo growth. Microb Pathog 1987; 2 : 249-257.

18. Poulain D, Vernes A, Fruit J. Variation de la structure antigénique parietale de Candida albicans : mise en évidence au niveau des blastospores d'un antigène $P$ dependant de leur origine. Sabouraudia 1980; 18: 61-68.

19. Poulain D, Tronchin G, Lefebvre B, Husson MO. Antigenic variability between Candida albicans blastospores isolated from healthy subjects and patients with Candida infection. Sabouraudia $1982 ; 20$ : 173-177.

20. Poulain D, Hopwood V, Vernes A. Antigenic variability of Candida albicans. CRC Crit Rev Microbiol 1985; 12: 223270.

21. Fruit J, Cailliez JC, Odds FC, Poulain D. Expression of an epitope by surface glycoproteins of Candida albicans. Variability among species, strains and yeast cells of the genus Candida. J Med Vet Mycol 1990; 28 : 241-252. 